\title{
USING A LUENBERGER OBSERVER TO ESTIMATE THE PITCHING MOMENT OF THE VEHICLE
}

\author{
Vu Van Tan
}

University of Transport and Communications

\begin{abstract}
Motion safety is an extremely important factor in automotive design. There are many solutions that are applied to enhance this feature such as optimizing the structural parameters of the car, using active systems such as braking, suspension, steering... When the vehicle suddenly changes the speed, there will be a change of mass between its axes and cause a moment rotating around the center of gravity of the vehicle. This moment is called the "Pitching moment". This factor causes the vehicle possibility to be lifted up therefore estimating this moment will help manufacturers figure out solutions the increase vehicle safety. In fact, it is difficult to measure the value of this moment and no sensors can be performed directly in real cars. This paper proposes a new method to estimate the pitching moment by using a Luenberger observer for the $1 / 2$ vertical half car model. The linear quadratic regulator control theory is also applied to design this observer. The simulation results in time domain with a real car model have shown the efficiency and accuracy of the proposed method with very small signal delay.
\end{abstract}

Keywords: Pitching moment; observer design; vehicle dynamics; passive suspension system; fault detection

Received: 16/9/2020; Revised: 15/11/2020; Published: 30/11/2020

\section{SỬ DUNG BÔ QUAN SÁT LUENBERGER ĐỂ ƯỚC LƯợig MỒ MEN CHUYỂN TẢI DỌC CỦA Ô TÔ}

\author{
Vũ Văn Tấn \\ Truờng Đại học Giao thông Vận tải
}

\section{TÓM TẮT}

Độ an toàn khi chuyển động là một yếu tố vô cùng quan trọng trong thiết kế ô tô. Có rất nhiều giải pháp được ứng dụng để nâng cao đặc tính này như: tối ưu hóa các thông số kêt cấu của ô tô, sử dụng các hệ thống chủ động như phanh, treo, lái... Khi ô tô thay đổi tốc độ đột ngột, giữa các cầu của xe luôn xuất hiện sự chuyển tải và điều này gây nên một mô men quay quanh trọng tâm của ô tô, được gọi là "Mô men chuyển tải dọc". Giá trị của mô men này càng lớn thì càng làm giảm tính ổn định và hiệu suất của ô tô, nên việc xác định chính xác mô men này sẽ giúp đưa ra những giải pháp tối ưu nhằm tăng tính an toàn cho ô tô. Trong thực tế, việc đo đạc được giá trị của mô men chuyển tải dọc còn gặp rất nhiều khó khăn và không có các cảm biến nào có thể thực hiện được trực tiếp trên ô tô thực. Bài báo này trình bày phương pháp mới để ước lượng mô men chuyển tải dọc bằng cách sử dụng bộ quan sát Luenberger kết hợp cùng phương pháp điều khiển linear quadratic regulator cho mô hình $1 / 2$ ô tô. Kết quả mô phỏng trên miền thời gian với mô hình ô tô thực đã chỉ ra sự hiệu quả và chính xác của phương pháp với độ trễ tín hiệu rất nhỏ.

Từ khóa: Mô men chuyển tải dọc; thiết kế bộ quan sát; động lục hoc ô tô; hệ thống treo bị động; xác định lồi

Ngày nhận bài: 16/9/2020; Ngày hoàn thiện: 15/11/2020; Ngày đăng: 30/11/2020

Email:vvtan@utc.edu.vn https://doi.org/10.34238/tnu-jst.3614 


\section{Introduction}

Nowadays, automotive vehicles are equipped with many technologies and intelligent systems and subsystems. This fact allows the vehicles to meet the requirements of safety and the driving comfort. Along with the braking and steering systems, which are witnessed as systems that can affect the car performance with astonishing records in improving comfort, stability and safety, the suspension systems also play a vital role [1]. When driving, in some situations, we can see that the car faces the ability of being lifted up after a breaking process or running in a high speed as showm in Figure 1 [2]. The caused force reasoned for this incident is called the "Pitching moment". This moment refers to the situation where upward force impacting on the vehicle is not in the center of gravity of the vehicle [3].

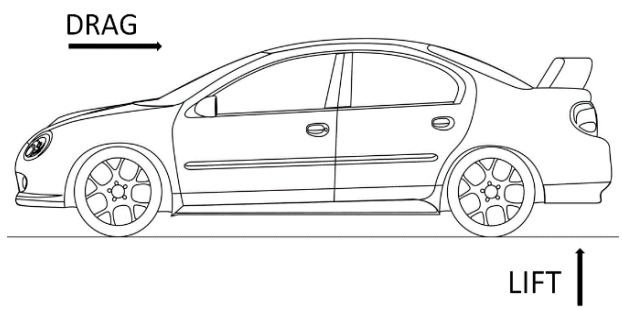

Figure 1. Forces affect on the vehicle in the longitudinal direction

The unbalanced force impacts cause the systems lift and negative lift and make the vehicle unstable, decrease the road holding and might lead to many critical situations [2]. The studies of the suspension systems offer effective ways to detect and estimate the negative impacts like the pitching moment. The suspension systems connect the vehicle body (chassis) and the wheels and constituted by three elements: an elastic element (a spring), a damping element (a damper) and a set of linking mechanical elements [1], [4]. Different types of springs, dampers and technologies used to distinguish the suspension into three types: a passive suspension (spring and damper characteristics are fixed) is the one of the simplest models to study about, an active suspension (an active spring or/and an active actuator) and a semiactive suspension (a spring and a semi-active damper). The third system could compromise both cost (component cost, weight, sensors, power consumption, etc.) and performance (comfort, handing, safety) therefore is a key interest for many researchers [1], [3]-[5].

Several problems of fault detection related suspension systems have been dealt with various approaches. In [6], the authors presented a way to design an estimator to detect system errors in linear systems, or an observer based on control theory in [7], control strategies for suspension in [1]. Some other associated substantial works have been tackled during the last decades.

The main contribution of this paper is to propose a method to design a subsystem related: "an observer" detecting the undesired factor (the pitching moment) based on LQR control theory [3], [7]. The vertical half car model is used to anticipate and evaluate the accuracy of the proposed method. The simulation results show that the estimated pitching moment is very close to the experimental data, the difference between them converts to zero in an acceptable period of time ( $\sim 5$ seconds).

The paper is structured as follows. Section 2 is devoted to the brief description of the half car model used for synthesis and validation. Section 3 presents the design method with the aim of anticipating and measuring the pitching moment. Section 4 describes the simulation analysis in the time domain. Finally, some conclusions are given in the last section.

\section{Vehicle modelling}

In this section, a longitudinal half car (pitch oriented) with a passive suspension is used for the analysis of the vehicle dynamic behaviors as in Figure 2. The model has 4 degrees of freedoms: vertical displacement of the center of gravity $\mathrm{z}$, pitch angle $\emptyset$ and vertical displacements of unsprung masses $z_{t f}, z_{t r}[1]$. 


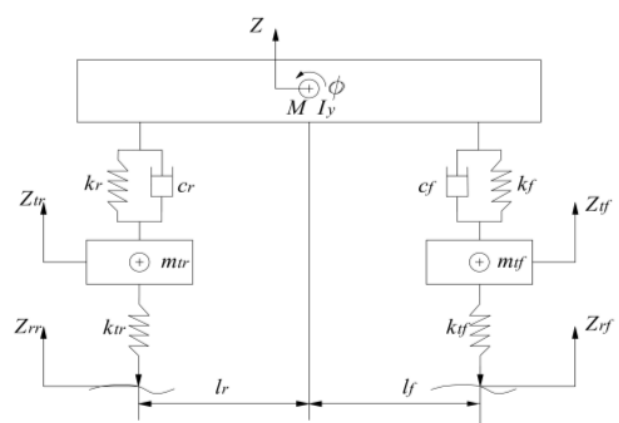

Figure 2. Vertical half car model using passive suspension system

The dynamic equations are given as:

$\left\{\begin{aligned} M \ddot{z}= & -k_{f}\left(z_{f}-z_{t f}\right)-c_{f}\left(\dot{z}_{f}-\dot{z}_{t f}\right)-k_{r}\left(z_{r}-z_{t r}\right) \\ & -c_{r}\left(\dot{z}_{r}-\dot{z}_{t r}\right) \\ m_{t f} \ddot{z}_{t f}= & -k_{f}\left(z_{t f}-z_{r f}\right)+k_{f}\left(z_{f}-z_{t f}\right)+c_{f}\left(\dot{z}_{f}-\dot{z}_{t f}\right) \\ m_{t r} \ddot{z}_{t r}= & -k_{r}\left(z_{t r}-z_{r r}\right)+k_{r}\left(z_{r}-z_{t r}\right)+c_{r}\left(\dot{z}_{r}-\dot{z}_{t r}\right) \\ I_{y} \ddot{\phi}= & l_{r}\left[k_{r}\left(z_{r}-z_{t r}\right)+c_{r}\left(\dot{z}_{r}-\dot{z}_{t r}\right)\right]-l_{f}\left[k_{f}\left(z_{f}-z_{t f}\right)\right. \\ & \left.+c_{f}\left(\dot{z}_{f}-\dot{z}_{t f}\right)\right]+M_{d y}\end{aligned}\right.$

where: $\left\{\begin{array}{l}\dot{z}_{f}=\dot{z}+\dot{\phi} l_{f} \\ \dot{z}_{r}=\dot{z}-\dot{\phi} l_{r}\end{array}\right.$

and $M_{d y}$ is the pitch moment.

Equation (1) can be written as this form:

$P . \ddot{Z}=N . \dot{Z}+H . Z+T_{1} \cdot M_{d y}+T_{2} \cdot \mathrm{W}$

$\Rightarrow \ddot{Z}=P^{-1} \cdot N \cdot \dot{Z}+P^{-1} \cdot H \cdot Z+P^{-1} \cdot T_{1} \cdot M_{d y}+P^{-1} \cdot T_{2} \cdot \mathrm{w}$

We set $\left\{\begin{array}{l}x_{1}=Z=\left[z, z_{t f}, z_{t r}, \phi\right]^{T} \\ x_{2}=\dot{x}_{1}\end{array}\right.$

So that we have the state-space representations for the system:

$$
\begin{aligned}
{\left[\begin{array}{c}
\dot{x}_{1} \\
\dot{x}_{2}
\end{array}\right]=} & \underbrace{\left[\begin{array}{cc}
0 & 1 \\
P^{-1} \cdot H & P^{-1} N
\end{array}\right]}_{A}\left[\begin{array}{l}
x_{1} \\
x_{2}
\end{array}\right]+\underbrace{\left[\begin{array}{c}
0 \\
M^{-1} T_{1}
\end{array}\right]}_{E_{d}} \\
& +\underbrace{\left[\begin{array}{c}
0 \\
M^{-1} T_{2}
\end{array}\right]\left[\begin{array}{c}
z_{r f} \\
z_{r r}
\end{array}\right]}_{E_{w}}
\end{aligned}
$$

Then we set $\left[\begin{array}{l}\dot{x}_{1} \\ \dot{x}_{2}\end{array}\right]=\dot{x}$ so that we have

$$
\left\{\begin{array}{l}
\dot{x}=A x+E_{d} d+E_{w} \\
y=C x+D\left[\begin{array}{l}
d \\
w
\end{array}\right]
\end{array}\right.
$$

As we assumed the pitching moment a slow variant signal, we also have $\dot{d}=0\left(d=M_{d y}\right)$. Therefore, we can consider $d$ as a state of the estimated system. We have the new state-space representation of the new system as follows [8]:

$$
\left\{\begin{array}{l}
{\left[\begin{array}{c}
\dot{x} \\
\dot{d}
\end{array}\right]=\underbrace{\left[\begin{array}{cc}
A & E_{d} \\
0 & 0
\end{array}\right]}_{A_{a}}\left[\begin{array}{c}
x \\
d
\end{array}\right]+\left[\begin{array}{c}
E_{w} \\
0
\end{array}\right]_{x_{a}} w} \\
y=C_{a} x_{a}
\end{array}\right.
$$

Where $x_{a}=\left[z, z_{t f}, z_{t r}, \phi, \dot{z}, \dot{z}_{t f}, \dot{z}_{t r}, \dot{\phi}, d\right]^{T}-$ the state vector; $y=\left[\ddot{z}_{t f}, \ddot{z}_{t r}, \dot{\phi}, z_{\text {def }_{f}}, z_{\text {def }_{r}}\right]^{T}$ - the output vector; $w=\left[z_{r f}, z_{r r}\right]^{T}$ - the disturbances; In order to simplify the process of evaluating the effectiveness of the proposed method, this paper uses a small 1/5 scaled car model equipped at the Gipsa laboratory as shown in Figure 3, with symbols shown in Table 1 and values in [5].

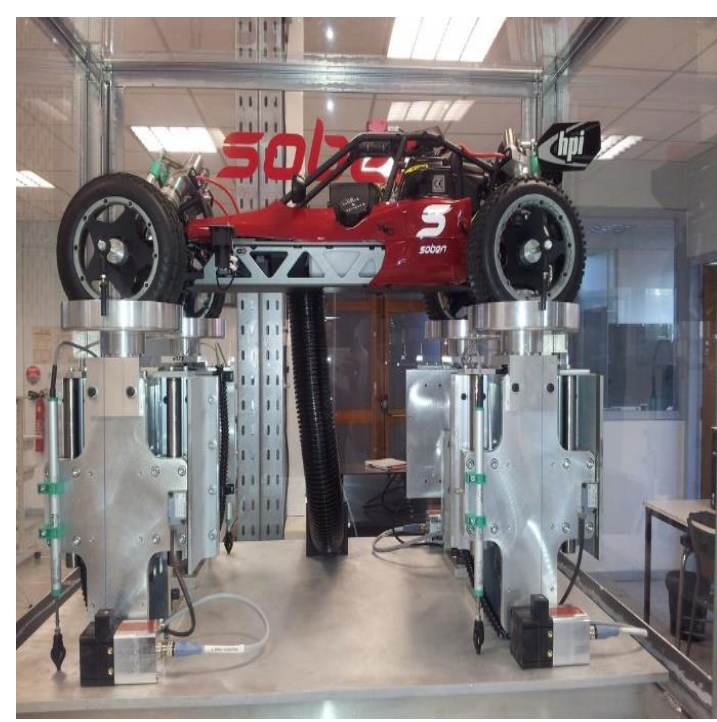

Figure 3. INOVE Sobencar testbed in Gipsa lab, France 


\begin{tabular}{|c|c|c|c|}
\hline Symbols & Descriptions & Value & Unit \\
\hline M & Sprung mass & 9.08 & $\mathrm{~kg}$ \\
\hline$m_{t f}$ & Front unsprung mass & 0.32 & $\mathrm{~kg}$ \\
\hline$m_{t y}$ & Rear unsprung mass & 0.485 & $\mathrm{~kg}$ \\
\hline$l_{f}$ & $\begin{array}{l}\text { Distance between the } \\
\text { centre of gravity and } \\
\text { the front axle }\end{array}$ & 0.2 & $\mathrm{~m}$ \\
\hline$l_{r}$ & $\begin{array}{l}\text { Distance between the } \\
\text { centre of gravity and } \\
\text { the rear axle }\end{array}$ & 0.37 & $\mathrm{~m}$ \\
\hline$k_{f}$ & $\begin{array}{l}\text { Linearized front } \\
\text { suspension stiffness } \\
\text { coefficients }\end{array}$ & 1396 & $\mathrm{~N} / \mathrm{m}$ \\
\hline$k_{r}$ & $\begin{array}{l}\text { Linearized rear } \\
\text { suspension stiffness } \\
\text { coefficients }\end{array}$ & 1396 & $\mathrm{~N} / \mathrm{m}$ \\
\hline$k_{t f}$ & $\begin{array}{l}\text { Linearized front tire } \\
\text { stiffness coefficients }\end{array}$ & $\begin{array}{c}1227 \\
0\end{array}$ & $\mathrm{~N} / \mathrm{m}$ \\
\hline$k_{t r}$ & $\begin{array}{l}\text { Linearized rear tire } \\
\text { stiffness coefficients }\end{array}$ & $\begin{array}{c}1227 \\
0\end{array}$ & $\mathrm{~N} / \mathrm{m}$ \\
\hline$c_{f}$ & $\begin{array}{l}\text { Front damping } \\
\text { coefficients }\end{array}$ & 563.5 & $\mathrm{~N} . \mathrm{s} / \mathrm{m}$ \\
\hline$c_{r}$ & $\begin{array}{l}\text { Rear damping } \\
\text { coefficients }\end{array}$ & 563.5 & N.s/m \\
\hline$I_{y}$ & The pitch inertia & 2.5 & $\mathrm{Kg} \cdot \mathrm{m}^{2}$ \\
\hline
\end{tabular}

$\left\{\begin{array}{l}\dot{x}=A x+B u \\ y=C x+D u\end{array}\right.$

where $\mathrm{A} \in R^{n x m}, \mathrm{~B} \in R^{n x m}, \mathrm{C} \in R^{p x n}, \mathrm{D} \epsilon$ $R^{p x m}$. The states can be estimated if the system is observable.

Therefore, we have a Luenberger observer form, which is a model-based estimator as follow [9]:

$$
\dot{\hat{x}}=A \hat{x}+B u+L(y-\hat{y})
$$

Where $\hat{y}=\mathrm{C} \hat{x}+\mathrm{Du}$. The equation (8) can be written as:

$$
\dot{\hat{x}}=(A-L C) \hat{x}+\left[\begin{array}{ll}
B-L D & L
\end{array}\right]\left[\begin{array}{l}
u \\
y
\end{array}\right]
$$

$\mathrm{L}$ represents the gain matrix of the observer. It has to be synthesized so that even though the initial estimate $\hat{x}(0)$ is not equal to the actual initial state $\mathrm{x}(0)$, as time passes the state estimate $\hat{x}(t)$ converges to the actual state $\mathrm{x}(\mathrm{t})$.

The appropriate matrix L will keep the error between the real system model and the reconstructed system (the observer model) expectedly small. The equation describes the error estimation is defined as:

$$
\begin{aligned}
& \dot{e}(t)=\dot{x}(t)-\dot{\hat{x}}(t) \\
& \dot{e}(t)=[A-L C] e(t)
\end{aligned}
$$

Remark: the control input does not appear because the input is fed directly into the observer through the $\mathrm{B}$ matrix. If the eigenvalues of (A-LC) are in the left halfplane, then $\mathrm{e}(\mathrm{t}) \rightarrow 0$ as $\mathrm{t} \rightarrow \infty$ and $\hat{x}(t)$ will converge towards $\mathrm{x}(\mathrm{t})$.

\subsection{Design an observer to measure the pitching moment using LQR control theory}

In the estimation error form of the observer, we have the equation (10):

$$
\dot{e}(t)=[A-L C] e(t)
$$

Comparing the finding of gain $\mathrm{L}$ with the finding of gain $\mathrm{K}$ in LQR control background, 
as gain $\mathrm{K}$ is in the equation $(A-B K)$, we can apply the LQR control method to find the gain $\mathrm{L}$ of the observer if we transpose the matrix $(A-L C)$ to have the similar form as $(A-B K)$ [7], [10].

$$
[A-L C]^{T}=A^{T}-C^{T} L^{T}
$$

The eigenvalues of $A^{T}$ and $\mathrm{A}$ have the same characteristic polynomial if $\mathrm{A}$ is an $n x n$ matrix. Therefore eigenvalues of $[A-L C]$ equals the eigenvalues of $[A-L C]^{T}$. When applying the LQR control method, we have: $(A, B)$ is changed to $\left(A^{T}, C^{T}\right)$ and $K$ is $L^{T}$.

The LQR problem has been studied for the time-varying and the time-invariant cases. We will only focus on the time-invariant optimal regulator problem.

Consider the linear time-invariant system (7):

$$
\left\{\begin{array}{l}
\dot{x}=A x+B u \\
y=C x+D u
\end{array}\right.
$$

where $\mathrm{A} \in R^{n x n}, \mathrm{~B} \in R^{n x m}, \mathrm{C} \in R^{p x n}, \mathrm{D} \epsilon$ $R^{p x m}$

$u=-K x$

The equation (12) represents the full state feedback control law. The closed-loop system is then given by the equations:

$\dot{x}=\underbrace{(A-B K)}_{A c l} x$

In control design, the eigenvalues of $A_{c l}=(A-B K)$ in equation (13) is affected by the gain of $\mathrm{K}$, the selection of $\mathrm{K}$ will give the closed-loop system has the desired behaviour. Since the eigenvalues have influents on the dynamic behaviour, we can obtain control goals by negative designed eigenvalues [11].

\section{Simulation analysis}

In this section, the pitching moment will be estimated in two circumstances with two different types of the inputs.

\subsection{Simulation scenarios}

In order to apply the proposed method, we need to meet some specific requirements. First, we consider the road profile is known and measureable. In this paper, the sine wave road profile at the frequency of $5 \mathrm{rad} / \mathrm{s}$ is used. Second, the pitching moment is considered as a slow variant (as listed above). In this study, two types of signals of the pitching moment will be implemented, namely step signal (step time: $15 \mathrm{~s}$ ) and sine wave signal (frequency: $2 \mathrm{rad} / \mathrm{s}$ ) [12], [3].

\subsection{Estimated pitching moment as the sine wave signal input}

Figure 5 shows the time response of the estimated signal when plugging the pitching moment $\hat{d}$ as a sine wave signal at frequency $2 \mathrm{rad} / \mathrm{s}$. The red and solid line represents the experimental data of the pitching moment, and the dashed green line is the estimated pitching moment of the observer.
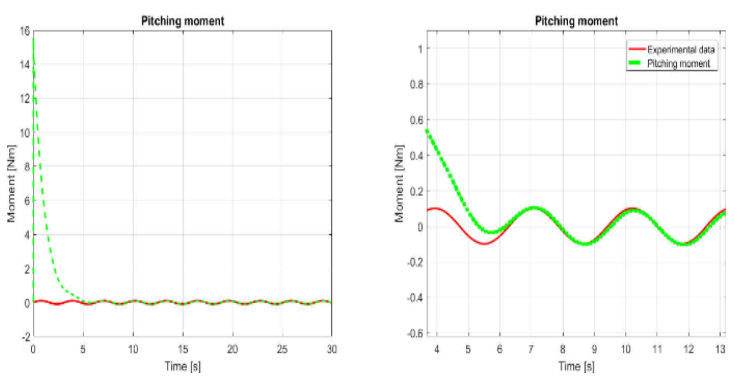

Figure 5. Time response for tracking the sine wave pitching moment

The simulation shows that the estimated pitching moment quickly tracked and followed the experimental signal in around 5 seconds after the observer started. Despite the quick tracking time, the observer overshoot in simulation results remained below $15 \mathrm{Nm}$, which is acceptably small. The balance between the overshoot and the tracking time of the estimation proves the efficiencies and accuracy of the observer.

Figure 6 shows the time response of the error during the estimation process. The dashed-red line represents the difference between the estimation and the experimental data 
(compared to 0 - the solid blue line). It is easy to see that the error quickly goes to zero [14].
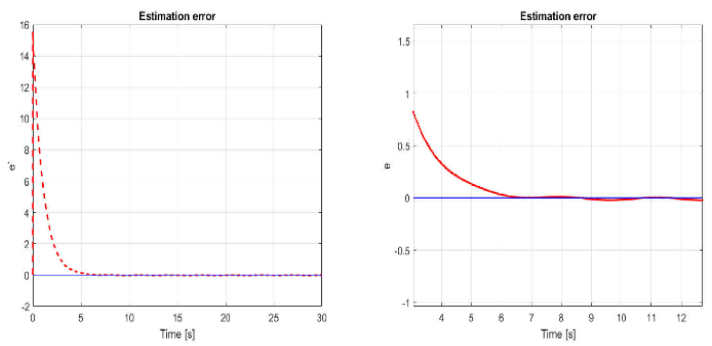

Figure 6. Estimation error in a sine wave behavior

\subsection{Estimated pitching moment as the step signal input}

Figure 7 shows the time response result of the second scenario when we have the pitching moment $\hat{d}$ as a step signal. The step time used for simulation is 15 seconds.
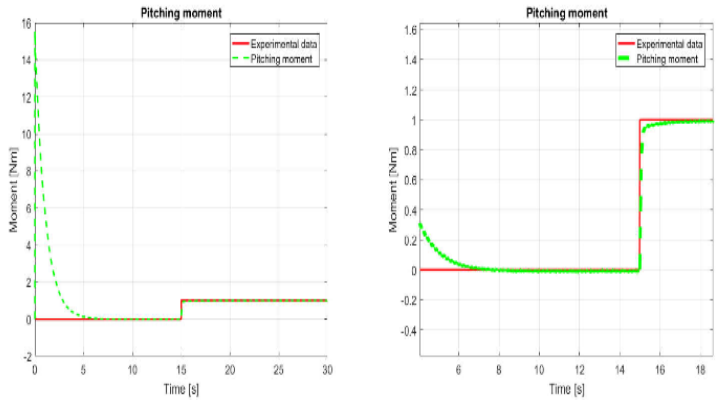

Figure 7. Time response for tracking the step pitching moment

The simulation results show the similar result as the first scenario when estimated pitching moment followed the original closely after a short amount of time. In this simulation, the overshoot and the tracking time were also balanced with the value of the overshoot remained below $15 \mathrm{Nm}$.
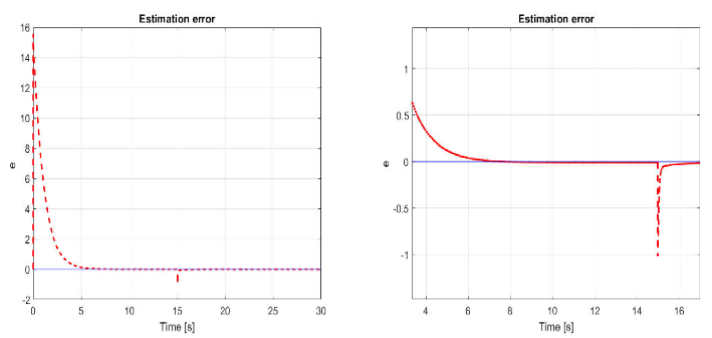

Figure 8. Estimation error in a step behavior

Figure 8 shows the error estimations of the estimated pitching moment when we used the step signal for $\hat{d}$. In this case, the dashed-red line stands for the difference between the estimation and the experimental data (compared to 0 - the solid blue line). The difference between them converged towards nearly zero through time.

From the results in both cases, we can see that the error quickly decreased to nearly zero after a short period of time when the original signal changes.

\section{Conclusions}

The observer or the estimator systems have been studied worldwide due to their advantages in both technical and economical way. The paper introduces the design method for estimating the pitching moment by using the Luenberger observer within the background of LQR control theory. The simulation results in the case of 4 degree of freedom with a hall car model showed the efficiencies and the accuracy of the observer when the overshoot value and the tracking time are balanced in an acceptable range. Also, within the paper, it has shown a possibility of reconstructing the original system to offers a more simpler way to estimate unmeasurable states and other factors.

\section{Acknowledgement}

The author would like to thank colleagues and students from the University of Transport and Communications and the Grenoble Institute of Technology for their assistance in conducting the evaluation on a real INOVE Sobencar in Gipsa lab.

\section{REFERENCES}

[1]. S. M. Savaresi, C. Poussot-Vassal, C. Spelta, O. Sename, and L. Dugard, Semi-active suspension control design for vehicles, Elsevier book, 2010.

[2]. Donut Media, "Wings and Spoilers; Lift and Drag; How It Works," 2018. [Online]. Available: https://www.youtube.com/watch?v=AXjiThF 1LXU. [Accessed Aug. 01, 2020]. 
[3]. H. L. Pham, "Intelligent Autonomous Vehicles For Road Safety Improvement," MA thesis, University of Transport and Communications, Grenoble Institute of Technology, 2019.

[4]. M. Sever, and H. Yazici, "Disturbance Observer Based Optimal Controller Design for Active Suspension Systems," IFACPapersOnLine, vol. 49, no. 9, pp. 105-110, 2016.

[5]. M. Q. Nguyen, "LPV approaches for modelling and control of vehicle dynamics: application to a small car pilot plant with ER dampers," PhD thesis, Grenoble Institute of Technology, France, 2016.

[6]. L. Mohamadi, X. Dai, K. Busawon, and M. Djemai, "Output observer for fault detection in linear systems," IEEE $14^{\text {th }}$ International Conference on Industrial Informatics, Poitiers, France, 2016.

[7]. F. L. Lewis, State Observer and Regulator Design, Text book, University of Texas Arlington, 2001.

[8]. H. L. Trentelman, A. A. Stoorvogel, and M. Hautus, Control theory of linear system, Springer book, 2012.
[9]. K. M. Passino, and N. Quijano, "Linear Quadratic Regulator and Observer Design for a Flexible Joint," Textbook, Department of Electrical Engineering, Columbus Ohio, US, 2002.

[10]. D. Butler, "Facts About Eigenvalues," Textbook, University of California, San diego, US, 2015.

[11]. Wikipedia, "State observer". [Online]. Available:

https://en.wikipedia.org/wiki/State_observer. [Accessed Aug. 02, 2020].

[12]. Wikipedia, "Pitching moment". [Online]. Available:

https://en.wikipedia.org/wiki/Pitching_mome nt. [Accessed August 02, 2020].

[13]. S. Y. Cheng, M. Tsubokura, T. Nakashima, T. Nouzawa, Y. Okada, and D. H. Doh, "Aerodynamic stability of road vehicles in dynamic pitching motion," Journal of Wind Engineering and Industrial Aerodynamics, vol. 122, pp. 146-156, 2013.

[14]. M. H. Do, "Observation and fault tolerant control for semi-active suspension system," Master thesis, Grenoble Institute of Technology, France, 2017. 